University of Warwick institutional repository: http://go.warwick.ac.uk/wrap This paper is made available online in accordance with publisher policies. Please scroll down to view the document itself. Please refer to the repository record for this item and our policy information available from the repository home page for further information.

To see the final version of this paper please visit the publisher's website. Access to the published version may require a subscription.

Author(s): Monder Ram, Paul Edwards, Mark Gilman and James Arrowsmith

Article Title: The Dynamics of Informality: Employment

Relations in Small Firms and the Effects of

Regulatory Change

Year of publication: 2001

Link to published version:

http://dx.doi.org/10.1017/S0950017001008455

Publisher statement: None 


\title{
The Dynamics of Informality: Employment Relations in Small Firms and the Effects of Regulatory Change
}

\author{
Monder Ram, Paul Edwards, Mark Gilman \\ De Montfort University of University of Kent \\ University Warwick at Canterbury
}

\section{and James Arrowsmith}

University of Warwick

\begin{abstract}
AвSTRACT This paper addresses two related issues: the effect of the 'regulatory shock' of the National Minimum Wage on small firms and the consequent effects on the commonly observed practice of 'informality'. It draws on a survey of such firms but primarily uses case study evidence from five firms to examine the processes at work. Detailed case studies of such firms remain rare, and they tend to analyse a largely unchanging world. We show how patterns of informality change over time. The regulatory shock had varying effects, as some firms moved up-market and others were pressed to the edges of the legitimate market and in some cases out of business altogether. In the firms moving up-market, informality was redefined into a more disciplined and formalised approach, while those going down-market relied even more heavily on family and other ties to survive. The NMW led to some improved wages, though there was also evasion, and it has sharpened the divide between the legitimate and illicit areas of business.
\end{abstract}

\section{(In)formality in Context}

Research on employment relations in small firms has developed considerably in the past ten years. First, it is no longer necessary to debate generic models of harmony and autocracy, for it has been established that different sorts of small firms have very different forms of employment relationship (Goss 1991), with the character of the relationship varying markedly between industries (Curran and Stanworth 1981). It is not so much the size of the firm, but size in combination with sectoral and other influences, which is important. Second, the longstanding stereotype of 'informal' small firms versus 'formal' large ones has been challenged. The fact that large firms, as much as small ones, are shaped by their context has been

Monder Ram is Professor in the Faculty of Business and Law, Department of Corporate Strategy, De Montfort University; Paul Edwards and James Arrowsmith are in the Industrial Relations Unit at the University of Warwick; and Mark Gilman is in the Business School, at the University of Kent. 
established through the firm-in-sector approach (Smith et al. 1990). The treatment of informality in small firms has also changed quite markedly, with the erroneous conflating of informal with harmonious work relations, evident in some early accounts (e.g. Bolton Committee 1971, see Curran 1991), being shown to have little theoretical or empirical justification. Informality cannot smooth away the power relations that shape the management process. Indeed, informality and the invocation of familial ideologies often evident in small firms can mask highly exploitative work regimes (Holliday 1995). As Wilkinson (1999: 214) observes, research is needed which shows how size interacts with other factors such as labour and product market influences, ownership, dependency, and relationships with customers and suppliers.

'Informal' employment relations may be defined as a process of workforce engagement, collective and/or individual, based mainly on unwritten customs and the tacit understandings that arise out of the interaction of the parties at work. As such, informality is dynamic rather than a fixed characteristic, and is highly context specific. Kitching (1997) shows that there are degrees of formality in small firms and also stresses that large organisations are not wholly formal. The Workplace Employee Relations Survey demonstrates quite high degrees of formality in small firms, for example the presence of written disciplinary procedures (Cully et al. 1999: 78,263 ). The second point reflects earlier work in larger firms which showed that a sharp distinction cannot be drawn between the formal and the informal aspects of employee relations, given widespread managerial reliance on informal understandings (Hill 1974; Armstrong and Goodman 1979). Informality in small firms is therefore a matter of degree and not kind, and its nature may vary as much between firms of a given size as between large and small ones. The purpose of the present paper is to move on from this point. We focus on the dynamics of informality. Most discussion has concentrated on identifying the patterns of informality, in a largely static way, though some research has stressed dynamics in the sense that employees and employers negotiate about pay and the like in the context of shifting market conditions (Ram 1994; Moule 1998). Less attention has been given to how informality evolves over time: the tendency has been to treat it as an essentially unchanging way of oiling the wheels, but we also need to consider in what direction the wheels are heading.

The particular stimulus to change that prompted the research is the potential 'regulatory shock' of new laws, namely, the 1998 Working Time Regulations (WTR) and the National Minimum Wage (NMW), which came into effect in April 1999. The former was the UK's first ever comprehensive statutory framework governing hours of work, dealing with maximum weekly duration of working time; rest times and breaks; paid annual leave; night working; and administrative requirements for monitoring (Hall et al. 1998). The NMW introduced a national pay floor for the first time in the $U K$, with the original adult hourly rate set at $\mathfrak{E}_{3}$.60 (Low Pay 
Commission 2000). In addition to the potential 'shock' occasioned by the introduction of the NMW and WTR at around the same time, there are two further reasons why their impact might be more pronounced on small enterprises. First, small firms tend to be characterised by low pay and benefits (McNabb and Whitfield 2000). Second, low pay and highly informal working (time) practices are particularly prevalent in the sectors that we focus upon: clothing (Phizacklea 1990; Ram 1994) and catering (Bailey 1987; Lucas 1995). Compliance with the regulations might therefore have constituted a 'shock' in two ways: substantively, through any impact on costs, and procedurally, occasioned by the new requirements for record keeping of pay and hours of work, and through any efforts by employers to recover cost increases by the more systematic supervision and monitoring of employees. Drawing principally on detailed case studies of five small firms, we show how the NMW and WTR affected patterns of informality, not as discrete shocks but as dynamic influences among others that shaped informality, often in subtle ways.

Small firms are embedded in a web of social and economic relationships that fundamentally shape working practices and managerial choice (Granovetter 1985). The extent to which they can accommodate regulations like the NMW is contingent upon the substance of these relationships. Economically driven explanations of wages take little account of how social relationships and customs at work shape the process of pay determination (see Edwards and Gilman 1999 for extended critique). Instances of individualised pay bargaining in small firms, far from demonstrating the unmediated power of the labour market, underline the pervasiveness of custom and indeterminacy within the employment relationship (Curran et al. 1991; Lucas and Radiven 1998). Yet, as Rubery (1997) argues, an overly concentrated focus on social embeddedness runs the risk of presenting too static a picture of work relations in which actors are governed largely by unchanging custom. This tendency is discernible in some 'culturalist' accounts of ethnic minority business activity, where ethnicity effectively blunts the conflict inherent in the capital-labour relationship (Werbner 1990). Some sociological accounts therefore stress stability of norms, when a dynamic analysis is required.

\section{Cases and Methods}

The case studies are drawn from a wider investigation of responses to the NMW and WTR in eighty-one small firms in three sectors, printing, clothing, and hotels and catering. These firms were identified using the advice of twenty-two business associations and similar bodies with which we developed extensive contacts. The study surveyed the firms before and after the introduction of the NMW, in the early spring of 1999 and 2000, through face-to-face interviews of the (owner-) manager and a member of staff. From this sample we were able to research five firms in more depth as case studies. These were located in the clothing and hotel 
and catering sectors, where the survey results were more contingent and ambiguous than those of the printing sector. We briefly refer to the overall results to introduce and contextualise our discussion, but the focus here is on the detailed clothing and catering case studies.

The larger study identified three main patterns of response. First, there are situations where the WTR and NMW had little effect. Under this 'business as usual' response, existing informal practices remained largely intact, with some minor adjustment. Employers adapted to, rather than wholly adopted, the regulations. In this they were aided by fairly stable trading conditions. Second, new laws can 'shock' firms into more efficient labour management practices (Edwards and Gilman 1999) which may reflect moves up-market. Third, increased costs can push firms to intensify work in an effort to recoup these costs. We found that this was rare, largely because the space for such intensification was often lacking, but we identified a slightly different dynamic, namely, moves down-market towards the illegal and grey areas of business or indeed out of the market entirely. We use five case studies to demonstrate the rationales and dynamics of each pattern.

The value of case-study work is worth underlining. A 1998 postal survey of hotels (Brown and Crossman 2000) shows that a large proportion of hotels had a strategy in place in that they reported planning to make either a connected series of cost-cutting measures or quality improvements. We do not dispute that such firms may want to behave strategically. However, there is always the doubt that the strategists are concentrated among the 30 per cent who replied rather than the 70 per cent who did not. And, if invited to identify a series of potential measures, managers might be tempted to indicate that they are pursuing them even if in fact they had no clearly formulated plans. As one of our sample firms put it, they had not even thought about using the NMW to rationalise payment systems until the researcher raised the possibility.

The cases comprised a 'leading edge' food manufacturer (PatCo) and restaurant (SajCo), an 'average' restaurant (BaltiCo), and two garment manufacturers typical of many operating in the West Midlands clothing sector (SweatCo and EndCo). The 'leading edge' small firms were sought in order to explore how the reality of shopfloor relations matched proclaimed commitments to high quality work processes. We use the term more loosely than elsewhere (see McGovern et al. 1998; Gratton et al. 1999: 19). We asked the twenty-two organisations involved in the research to identify possible leading-edge firms; we discovered what the firms themselves said; and our own approach was simply to treat the firms in question as relatively 'up-market' (in business terms) and then explore what happened to their employment arrangements under the NMW and WTR. A senior manager at PatCo, which employed some thirty workers, ${ }^{1}$ claimed it was a leading-edge firm on the criteria of investment in technology; commitment to training; and that it was a 'market leader'. Likewise, SajCo's claim to be 'leading edge' was based upon its 
reputation for 'quality', and its longevity (it had been in business for over twenty-five years). However, in terms of concrete working practices, it had much in common with the other restaurant in the study, BaltiCo. Our 'leading' cases clearly aimed to establish a particular market position and they differed from other firms in their sectors in ambition; how far and by what means this ambition was realised is one of the research questions.

In contrast, the two clothing firms (SweatCo and EndCo) hail from what some might consider as the 'sweatshop' segment of the clothing sector (Hoel 1982; Mitter 1986). 'Leading edge' small clothing companies were much more difficult to find. Virtually all were struggling to some degree, which is not too surprising for a sector officially acknowledged to be 'currently facing the greatest challenges in its history' (TCSG 2000: 5). In the event, both clothing case studies were fairly typical firms likely to be prime targets for the NMW. The case of EndCo is particularly illustrative, since it was first studied by one of the writers some ten years ago. It closed down during the course of the study; but it was possible to interview the owner afterwards to explore the reasons for closure, including the effects of the NMW and competitive pressures. The two leading-edge firms, which were also slightly larger than the other cases, were visited on at least eight occasions and an element of direct observation was also possible. Repeat interviews were conducted with management in each of the other firms studied and interviews were also held with a substantial number of employees.

Hence, the selection of the firms was informed by a 'multiple case logic' (Eisenhardt 1991; Eisenhardt and Bourgeois 1988). We are not seeking here to generalise to a population but to examine 'soft' processes and dynamics within each case, supported by some comparisons within and between sectors to generate additional insights. We generalise to the level of theory rather than any statistical notion of representativeness (Edwards 1992).

\section{Business as Usual: SajCo and BaltiCo}

Where pay was previously below NMW rates in the hotel and restaurant trade, results from the larger study found that the dominant response was to accommodate to it. Accommodation meant paying the NMW and doing little else, while largely ignoring the WTR: the laws were not enough of a shock to change working practices. This reflected three considerations which managers articulated: the fact that most other firms were paying the NMW so that there was little risk in doing so too; its relatively low level which meant that any cost increase could be absorbed or passed onto customers; and finally the practical difficulty of changing work organisation as a compensating response. Two quotes illustrate the latter point: 'there is a limit to what we can do' (hotelier); 'it's not like in big companies where you can cut one member of staff and get the rest to work harder. In a small 
firm there is no room for manoeuvre - if you cut a job it wouldn't get done' (caterer). The following two cases, SajCo and BaltiCo, illustrate this dominant pattern.

Although both are purveyors of South Asian cuisine, our two 'Indian' restaurants represented markedly different market segments. BaltiCo was located in the middle of Birmingham's 'Balti Quarter', an area with a reputation for inexpensive South Asian food frequented by young professionals and students. The demand for this form of eating out has led to a proliferation of Balti houses that compete mainly on the basis of price. The owner was aware of the contradictory forces operating in this market. On the one hand, a concentrated group of Balti houses had beneficial cluster effects since more people came to the area, thus increasing the chances of picking up passing trade; but a growing number of similar restaurants was reducing the supply of potential customers. In terms of coping with the competition, the owner commented 'we give them good food, look after the customers, and hope for the best ... What else can we do?' Of particular importance was the need to keep their 'regular' customers happy. SajCo too had a core of regulars (albeit more affluent than those of BaltiCo) that accounted for its longevity in the restaurant trade. The importance of retaining their custom necessitated particular attention to the relationship with key staff, notably the chefs. SajCo's reputation was therefore based upon culinary 'distinctiveness' and 'quality'. It had few direct rivals, and did not compete on the basis of price.

The work of chefs was central to the aim of retaining a regular client base. In essence, both restaurants had to maintain a balance between harnessing the creative endeavours of these key workers, and remaining competitive. In the case of BaltiCo an important factor was the active 'hands-on' role that the proprietor himself played in all aspects of the business, from cooking to the serving of customers. He suggested that this was important, since staff could be replaced if they went beyond a particular point:

It's a delicate situation ... but if they [chefs] say 'I want $x$ amount of money', and you need them, then you give them the money. But you start looking around ... to get someone to replace him ... You can't afford to be messed around .... There's a limit to what we will take ... Because I can do the work myself, they know the limit.

The reputation of SajCo's chefs has already been mentioned; the manager claimed that 'the biggest headache is the endless list of demands they make of me'. Amar, the head chef, had a number of relatives working alongside him in the kitchen. His uncle is a chef and his eldest son is a waiter, who he is currently training to be a chef. His youngest son also works in the kitchen as a helper. Amar maintained that 'it is easier to work with family ... there is no conflict ... If I am late, they will cover for me; and I will cover for them.' An example of this 'flexibility' was the imminent departure for India of Amar's uncle. He would be away for over a month 
in the run-up to the busiest time of the year, pre-Christmas. Amar said 'We will cover for him, it's no problem'. He usually worked sixty hours per week. Neither owners nor workers were aware of the WTR. Amar was paid $\mathfrak{E}_{5}$.0o per hour net. When asked how he secured a pay rise, he said that it was 'hard' to get, and had to be 'sorted out with gaffer'. He maintained that he often had to say 'give me a pay rise or I leave' if he wanted to get a pay increase. He found out about pay and conditions elsewhere through his family connections: 'We have relatives in every restaurant ... Wages news travels very fast ... We find what they're getting, whether their taxi home is paid for and other things.'

Wages for kitchen workers and waiting staff in both restaurants were, in most cases, below the NMW. They were usually paid per session, but it was often difficult to anticipate how long this session would last. For example, waiters at SajCo received $\mathfrak{E} 15$ per evening session, which notionally extended from 6.30 p.m. to 11.30 p.m. However, this could be much longer if there were customers to serve; there were no overtime payments. A similar situation pertained at BaltiCo. The firm employed two students to cover the busy times on Friday and Saturday evenings. They were paid $\mathfrak{L}_{15}$ 'cash in hand'. Another waiter, Salim, worked full-time. His usual working hours were from 6 p.m. to 1 a.m. However on Fridays and Saturdays, he would rarely finish work before 3 a.m. Salim was paid a wage of $\mathfrak{k}_{105}$ in cash (again, there were no overtime payments). This sum was supposedly after deductions; but Salim was not sure how much money was been deducted, or for what purpose. Although Salim worked on a full-time basis, he is officially recorded as a part-time worker. The arrival of the NMW had not resulted in an increase in wages; rather than any substantive impact, its main effect was to alter the number of hours that were recorded. The owner explained,

We give them cash in hand, but we don't show all the wages, because then it would affect their family credit and that stuff. What we do [prior to April 1999] is show 30 hours at $\mathfrak{E}_{2.50}$ or $\mathfrak{E}_{3}$.00. Since April, we show it at $\mathfrak{E}_{3}$.60. We have to do that because the social security people will come down [to investigate].

Despite low levels of pay, a flexible and apparently relaxed approach to the management of staff seemed to prevail with waiting staff. There was no direct monitoring of time keeping and attendance, and workers maintained that they were treated 'fairly'. Mirza of SajCo claimed that the 'relaxed' atmosphere was an important feature of work relations in the firm. He was renowned for turning up late: 'I am always late, but they don't crack down. As long as they see that I get straight to work, they don't mind ... Sometimes because I know I'm late, I will stay after hours until the customers go.' Such informal and ostensibly paternalistic work relations have been noted in other studies of ethnic-minority owned restaurants (Bailey 1987; Herman 1979; Ram et al. forthcoming). To some extent, they stem from the embeddedness of social ties, or 'ethnic solidarity' (Zhou 1992); but perhaps more 
importantly, they are shaped by the nature of work in restaurants. For example, the erratic flow of customers is a feature of restaurant business; working time is therefore variable and customers perform the monitoring of staff without the need for ongoing and direct managerial intervention. To this end, the manager of SajCo commented,

\begin{abstract}
Sometimes I think I'm too lenient. But I know when it's busy, they'll all stand up and be with me and work hard. I mean, it's quiet now ... Look [points to a waiter] he's reading his paper and having a coffee, it makes no difference to me .... So if ten customers come in together, they'll know how fast they have to move; if two come in, they will know how fast to move. So really, it would be wrong to keep pressure on them all the time.
\end{abstract}

In sum, the nature of the market and the comparative stability of the client base of both restaurants was a key factor in explaining why informal employment relations were maintained, and how the NMW was accommodated (or avoided) with relative ease. Procedural adjustments were limited and cost implications contained. Neither market pressures nor employment regulations posed a serious threat to the web of dependency relationships that characterised working life in both firms. Management relied on the skill and creativity of chefs. This was usually nurtured over a considerable period of time, as the long tenure of chefs in both restaurants demonstrates. Relationships with more transient waiting staff were also highly informal; this reflected both the kind of social relations in the firm and the erratic nature of restaurant work. These workers were often paid below the NMW, but basic pay was seen in the context of other factors that comprised the overall reward package. These included the limited labour market opportunities of these workers; the 'give and take' approach to working hours; and the provision of 'extras' including free food and drink, tips, and transport home. However, as the manager of SajCo suggested, if the NMW 'went too far', or workers insisted on their rights, he would have to 'look at these other things'. Hence, it was clear that the potential regulatory shock was absorbed by informal understandings. Management, in the case of waiting staff at least, was able to keep costs down whilst retaining the flexibility necessary to cope with irregular work flows. Workers clearly had limited options; but they valued work relationships and trade-offs around working hours. An insistence on the NMW would imperil this and the non wage-element of the overall reward package. Both parties, therefore, had a vested interest in retaining the informal status quo.

\title{
Disciplined Growth: PatCo
}

The hotel and catering sector also contained some examples of a more positive reaction to the NMW in the overall study. For example, the manager of one of the larger firms, with several shopping centre restaurants, said: 
I think the minimum wage and working time regulations have focused our attention on this [pay and working time arrangements] a bit more - which is an indictment of ourselves that we needed this to prompt us! When you are small you do a lot of things by the seat of your pants, there is no vast structure with people specialising [in HR].

The WTR prompted the company to extend its holiday entitlements to Saturday staff. In terms of pay, the level of the NMW, just below established rates, brought home to the owner-manager that pay levels might not be as competitive as previously thought:

The minimum wage made me realise, I always thought we were good payers - for the retail food trade, and there are a lot of unscrupulous operators - but it makes you think whether you are as good as you think you are.

As a result two new higher pay bands of $\mathfrak{E}_{4}$ and $\mathfrak{E}_{4} .20$ were introduced, linked to skills development. Crucially, the business was starting to perform particularly well, which justified the increase in costs.

Our case study, PatCo, had gone a step beyond these positive but essentially reactive approaches. This was associated with expansion and investment as part of a sustained move up-market, in terms of product quality, volumes and processes, with consequent effects on the nature of informality. PatCo is a specialist manufacturer of ethnic food products. Its original customer base mainly comprised local food take-away outlets and grocery stores. These customers have become less important since PatCo started supplying the major supermarkets some three years ago.

The owner of PatCo claimed that the NMW had little impact, largely because the firm had anticipated the introduction of the legislation. He also maintained that the company had had 'a three year-plan to achieve, and possibly go beyond the rate ... We pegged our rate at $\mathfrak{L}_{3} .80$ without any adverse effects.' In 1996, production operatives were paid $\mathfrak{E} 2.70$ per hour. In 1999, there were three pay bands for production workers (managers were paid between $\mathfrak{E}_{18}$, ooo to $\mathfrak{L}_{23}$, 000 per annum),

1. $\mathfrak{E}_{3} .80-\mathfrak{E}_{4}$.80: Production operatives

2. $\mathfrak{E} 4.80-\mathfrak{E} 5.80$ : Team leaders

3. $\mathfrak{E} 5.80-\mathfrak{E} 6.80$ : Supervisor

According to a senior manager at PatCo, there were reasons, other than the NMW, for the company's 'three years of continual change'. First, the owner had a goal of being the largest supplier in his field ('the owner is a catalyst ... We're driven by his personal ambition'). Second, the influence of the market place:

We're also driven by the market. Once you get into one supermarket, it's easier to get into others ... It's like being on a treadmill, you can't get off. As you grow, you are forced to employ more specialist people and the pressure grows ...

In the past three years, PatCo had recruited specialists in personnel, production and finance. This expertise was required to handle the pressures emanating from the 
market and regulatory environment. PatCo had also spent $\mathfrak{L}_{50,000}$ on new plant and machinery in the preceding nine months. The aim was to save on labour costs, and in the words of the owner-manager, 'to get the volumes to supply the supermarkets'. It was also imperative that there was 'consistency of product'. Although PatCo's capacity to produce such quantities of its specialist product meant that it had few direct competitors, the company's dependence on powerful customers gave them little leeway in reality.

With the supermarket, you have absolutely no choice whatsoever. You have to abide by them. For instance, with Asda, we have to deliver seven days a week, not our preferred. Price increases are a no no; they keep wanting to knock you down. We had to invest in Electronic Data Interchange; orders come down a phone line to our computer, all transactions are done in minutes. (senior manager)

This customer-driven pressure narrowed the scope for informality on the shopfloor.

We output control all our production staff ... We know what is produced every hour of the week ... We have data sheets of everything that we produce in every department ... And we know what is despatched to each customer ... At the end of the day, we know how many products have been manufactured, and who has manufactured what ... We need to know that because of total traceability ... It's part of ISO9002 ... Traceability is driven by the customer ... It's customer-led. (owner)

The new machinery, introduced to cut costs and labour, had to be 'kept going'; and it was duly monitored with this objective in mind. Illustrating this point, one of the production workers made reference to the presence of closed circuit television on the shopfloor:

They're there to keep on eye on us all the time, to make sure that we are in the right place. It makes you feel like little children. They know straight away when one of the machines isn't working. They phone down to me to ask what's going on.

The new machinery also narrowed the scope for employee discretion; and management were, in the words of one respondent, 'making fewer compromises'. As the production manager explained,

In the last two years, we've gone from being very laid back to just laid back. We've tightened up on time keeping and attendance ... We've got a swipe card system so we can monitor it. We can say, 'You have had twelve days off this year, why?' That allows us to start disciplinary procedures. This was never done in the past. Now we have to be consistent ... The culture when I started with ... it was a case of 'what hours can you do, we will fit around you'. Now it has changed; it is a case of 'these are the hours that you do'. Because of the production system, you need the full team here.

Furthermore, there was little leeway in terms of pay. Although the owner maintained that there were annual pay rises (a claim disputed by some of the workers), there was little negotiation over the level of increase.

It's been my decision. I will award what I believe that we can afford on the figures that we currently have. But we're very dubious to award very high amounts, if we don't get $\mathrm{X}$ 
amounts of orders ... we give them a small amount of pay. So we are very careful that we don't overstretch our own facilities to actually pay them.

Despite the narrowing of the scope for informality, management still had to persuade workers to accept these conditions, and secure their consent to the process of change. A form of organised autonomy therefore emerged in the guise of more formalised approaches to labour management. The emphasis on formal training in the firm was an example of this. In a discussion on how candidates for training were selected, the owner remarked,

It's the level of aptitude in the company, the level of skills that they picked up, and their commitment. We sit and discuss it, and say that 'We believe that a course, an NVQ level 2 or 3, will benefit you and the company' ... It's a means of keeping them in the company.

However, it was equally apparent that the importance attached to training was also shaped by the combination of customer and technological pressures. For example, one manager maintained that, 'the customers wanted to see NVQ training for staff. Achieving the Tesco contract triggered a major growth spurt ... We had to show them that we had a system to get their approval.' There was also an ensuing pressure to ensure that workers were technically equipped to operate the machinery that was servicing these customers. To this end, the owner commented, 'Once you have put up the capital cost of equipment, ... it's of a higher specification ... we need to train the staff up to do the job.'

In addition to the provision of training, the firm began to have regular meetings involving all levels of staff. For example, managers, team leaders and production operatives each had their own meetings, which were usually minuted. Explaining the rationale for the meetings of production operatives, a senior manager commented,

Once operators are involved, you can have brainwashing [he then corrected himself, and said 'brainstorming'] meetings ... As you progress with these, you can say 'we need to stream line procedures; we need to reduce waste' ... It's a continual learning process ... If you can do these things, it relieves the boredom of work, and helps them become a part of the team ... It's a means of motivating them, and is probably better than giving them a 1op pay rise.

However, the content of these meetings did not extend to wider consultation or provision of information. The workforce was not informed about the WTR, even though they had been in force for more than six months. The manager in charge of personnel matters maintained that holiday entitlements could easily be accommodated. He also claimed that very few employees worked over 48 hours, so this aspect of the regulations was unlikely to affect them. However, because of demands imposed by the customers (i.e. supermarkets) for 'seven day delivery', it was necessary for some employees (despatch workers and drivers) to work on Sundays. This amounted to six employees, some of whom were likely to be affected by the 
WTR. If so, the manager would approach them on the expectation that they would agree to 'opt out' of the relevant provisions. 'If they are likely to work more than forty-eight hours, they can opt out. I will approach them, there's no problem with that.'

Finally, the owner made it clear that if workers would 'buy into' the company, there would be scope for them to develop their roles. For example, Ben left school with few formal qualifications, and was unemployed for a considerable period of time. He was alerted to the job of van driver at PatCo through the local job centre. He joined the firm seven and a half years ago, and is now the third longest serving employee. From his initial role as van driver, he has worked his way into a managerial post. His current role is that of a 'project manager', which involves 'looking after the factory and the equipment'; he is also in charge of health and safety. He says:

I feel that I am being groomed for better things ... I would like to stay with the company ... I said to [the owner] 'this place is mine as much as it is yours'. I've put the effort and hours in ... This is one of the few jobs that I've had that I turn up not just for the money ... It's not a means to an end ... I was walking past the job centre the other day, and I saw a job that I could do easily for $6 \mathrm{k}$ [ $\mathfrak{E 6 0 0 0}]$ more than I'm getting now. I hesitated for a second, then I just kept walking ... But many times in the past, in the early days, they stuck by me... They could have sacked me many a time ... They stuck by me, I will stick by them.

Hence, PatCo's planned accommodation of the NMW, investment in new equipment, and comparatively 'sophisticated' management practices were conditioned by relations with a powerful set of customers. The price of securing contracts with the supermarkets was the need for a system of production that necessitated closer monitoring and 'traceability'. Greater selectivity of workers was required to ensure that the new equipment operated efficiently. A key objective of the programme of training and workers' meetings was to ensure that, in the words of the owner, employees would 'buy in or get out'. This altered the character of informality, and created a more formally regulated workplace. However, there were counter-tendencies. For example, the continued presence of specialist workers is contingent upon the realisation of the firm's growth objectives, and consequent financial benefits. This could be a potential source of instability if PatCo's plans go awry. Moreover, continuing recruitment difficulties mean that the firm may experience problems in the trend towards greater selectivity; hence, a greater degree of flexibility may once again have to be introduced to the recruitment process.

\section{Desperate Measures: SweatCo and EndCo}

Evidence from the few clothing firms that attempted to move up-market in the overall study paints a similar picture of a more managed informality. Piecework 
systems were often removed because of their complexity. At the same time, closer monitoring of staff was introduced. For example, a trouser manufacturer tightened up on monitoring 'to bring them up to speed'. They also terminated the customary paid breaks arrangement (which triggered a dispute and sacking which led to a tribunal case) and ended employee flexibility over hours. In fact, virtually all the clothing firms visited in the survey part of the research said that they were worse off than a year before. A few had shut down and employment levels were reduced to some extent in almost all the rest. This was blamed primarily on deteriorating market conditions, though the new regulations were sometimes reported to have significantly increased costs. Among firms in our survey, the NMW had major implications for businesses that previously relied on piece-working. Many ownermanagers blamed it for increasing costs and falling productivity. The problem was not just the administrative complexity of monitoring and keeping records of each worker's weekly income for purposes of the NMW. Highly variable earnings meant that even the most productive workers sometimes earned less than $\mathfrak{E}_{3} .60$ an hour. Most firms in this group therefore took the opportunity to switch to measured day work. One manufacturer said that they 'have had to change everything' as a result of the NMW. It was also commonly claimed that productivity was down as a result: 'the minimum wage is a bad thing, not so much in actual pay terms but because there are no incentives any more'. Tighter controls were therefore usually introduced to monitor employees, and closer attention was sometimes paid to the training of poorer performers in the light of recruitment problems.

Market pressures on the two case-study clothing firms grew increasingly intense. The story of the response can be told briefly, but it is none the less significant. EndCo's main customer was a larger garment manufacturer which accounted for 90 per cent of EndCo's production. EndCo's proprietor maintained that the rising tide of imports and low-wage competition from the Far East were imposing considerable pressures on his main customer. The arrival of the NMW proved to be the final straw, leading quickly to the closure of the business, and EndCo followed suit. However, EndCo's demise was not quite a sudden one, as the firm struggled along in a desperate bid for survival, including resorting to making counterfeit branded clothing. The owner relied on his close friend, the owner of SweatCo, to provide him with this extremely slender lifeline. But it was only a temporary reprieve.

During the last two years, SweatCo had also begun to produce counterfeit clothing to supplement its narrow customer base. Much of this merchandise went directly to market traders. Because of the illegal nature of the product, the company relied heavily on particular homeworkers (usually extended family members) or trusted owners of other small manufacturing firms to produce these goods. In effect, it was retreating further into family networks. Interviews with two SweatCo homeworkers revealed pay levels of around $\mathfrak{E}_{150}$ for a working week that was in usually in excess of fifty hours. There were no holiday entitlements, overtime 
payments (despite the erratic nature of clothing work), or sick pay. Employees were aware of the NMW (though not the WTR); but felt their labour market options were limited.

A number of points emerge from the experiences of EndCo and SweatCo. Although the firms operated in a highly competitive and volatile market, customers were interested in price rather than the nature of work organisation in the case firms. Hence, unlike PatCo (and the firms studied by Rainnie 1989), owners had space to organise the production process. In previous years, this process was expedited by a negotiated order not unlike that noted in the two restaurants discussed earlier. However, given the severity of competition, narrow margins, and lack of resources to invest in technology, owners resorted to the intensive utilisation of informal networks to generate a supply of labour. Although this modus operandi had been sufficiently flexible for SweatCo and EndCo to survive for over twenty years, its continuation is open to question. Endco's demise illustrates clearly that the mobilisation of social ties is not sufficient to withstand the fierce competition that is now so much a feature of this market segment. Years of operating in this informalised manner meant that the firm was ill equipped, both in terms of financial and human resources, to consider alternative ways of handling the competition. SweatCo has survived by fiddling around and going deeper underground; there is some doubt over how long it can continue to operate in this precarious fashion.

\section{Conclusions}

These cases do not identify a clear-cut regulatory shock that one could attribute to the NMW or WTR. The biggest influence on the firms was the product market so that, for example, stable conditions in the restaurants led to little disturbance in existing relationships, whereas worsening conditions in clothing were critical to many firms in the sector. This is not, however, to say that the shock was simply absent. In clothing, it was one factor that made life more difficult, particularly where, as here, firms had formerly relied on piecework. This payment system had in effect legitimised low pay on the grounds of low skill and productivity. With the arrival of the NMW, this approach was no longer possible, unless the firm went 'off the books', as several in our study did. In restaurants, and arguably elsewhere too, the NMW sharpened the divide between the formal and informal sectors of the economy. In the past, many firms operated a payment system of paying so much per week and then expecting workers to work the hours necessary to meet demand. With the NMW, where average pay was below the $\mathfrak{E}_{3} .60$ level, such a firm has to make an explicit decision whether or not to go off the books.

The two clothing firms illustrate how a regulatory shock can push a firm over the edge, even one such as EndCo which had survived for a considerable time. This kind of re-structuring is of course a constant feature of capitalism. The rapidly 
tightening competitive conditions of the late 1990 os resulting from the combination of more direct foreign competition and the re-organisation of the supply chain reduced the size of the niche in which many British firms had survived. The interesting question is the overall effect on the sector. It is sometimes assumed that low-paying and inefficient firms are simply squeezed out of the market, whereas we have shown that some firms, like SweatCo, are pushed towards the edge of legitimate trade. The policy issue is then the balance between such firms and those that have either absorbed the NMW or gone up-market. The dynamics of informality here are the obvious ones of trying to make a living and pressing employees to accept changes, and often cuts, in pay and conditions.

As for moves up-market, PatCo was somewhat unusual in being able to find a market niche and the capital to allow it to occupy it. Its expansion and investment in technology led to an increased proceduralisation and formalisation of employment relations. In the process of moving from one state to another, which cannot be detected by one-off surveys, the firm had not eliminated all informality. It retained elements of an informal approach to facilitate the retention and recruitment of employees, while decisions on pay increases remained at managerial discretion. As argued at the outset, all firms combine formality and informality just as they combine control and consent. The balance differs as conditions vary.

The case studies show the uncertainty of firms' processes of adjustment. From the owners' point of view, these processes reflect a rational response to changing circumstances. Rationality should not be equated however with a careful strategy. Surveys of the kind conducted by Brown and Crossman (2000) usefully show that small firms are not without a strategic vision, but answers to questions asked at one point in time encourage a more coherent view of developments than is apparent when events are seen as they unfold. In short, small firms' behaviour is a mix of vision and opportunism, as is also true of large firms, as the debate between 'planning' and 'emergent' views of strategy has shown (Mintzberg et al. 1998).

The nature of 'informality' in small firms should not, therefore, be taken at face value. Too often it is accepted as an inevitable product of entrepreneurialism and close interpersonal relations in the workplace, promoting individualised and ad hoc patterns of decision-making and behaviour. In fact, it is structured by external influences relating to the nature of the product market and the characteristics of the available and existing labour force. It is also shaped by the demands and constraints imposed by existing modes of work organisation and technology. There is real scope for management choice, but within certain limits, and as circumstances change the nature and extent of informality adapts. 
for their advice, and to Anthony Ferner and the three anonymous referees for their comments on an earlier draft.

NOTE

1. Employment levels of the other case firms were: BaltiCo, 6 workers; SajCo, 10 workers; EndCo, 15 workers; SweatCo, 10 workers. However, not all these were employed 'on the books'.

REFERENCES

Armstrong, P., and Goodman, J. F. B. (1979) 'Managerial and Supervisory Custom and Practice', Industrial Relations Journal, 10, 3, 12-24.

Bailey, T. (1987) Immigrant and Native Workers, Boulder: Westview Press.

Brown, D., and Crossman, A. (2000) 'Employer Strategies in the Face of the National Minimum Wage', Industrial Relations Journal, 31, 3, 206-19.

Cully, M., Woodland, S., O’Reilly, A. and Dix, G. (1999) Britain at Work, London: Routledge.

Curran, J. (1991) 'Employment and Employment Relations in the Small Enterprise', in J. Stanworth and C. Gray (eds.), Bolton 20 Years On - The Small Firm in the 1990s, London: Paul Chapman on behalf of the Small Business Research Trust.

Curran, J. and Stanworth, J. (1981) 'Size of Workplace and Attitudes to Industrial Relations in the Printing and Electronics Industries', British Journal of Industrial Relations, 19, 1, 14-25.

Curran, J., Kitching, J., Abbott, B. and Mills, V. (1993) 'Employment and Employment Relations in the Small Service Sector Enterprise', ESRC Centre on Small Service Sector Enterprises, Kingston Business School, mimeo.

Edwards, P. K. (1992) 'La recherche comparative en relations industrielles: l'apport de la tradition ethnographique', Relations Industrielles, 47, 3, 411-36.

Edwards, P. K., and Gilman, M. (1999) 'Pay Equity and the National Minimum Wage', Human Resource Management Journal, 9, 1, 20-38.

Eisenhardt, K. (1991) 'Better Stories and Better Constructs: the Case for Rigor and Comparative Logic', Academy of Management Review, 16, 4, 620-27.

Eisenhardt, K., and Bourgeois, L. (1988) 'Politics of Strategic decision making in high-velocity environments', Academy of Management Journal, 31, 6, 737-70.

Goss, D. (1991) 'In Search of Small Firm Industrial Relations', in R. Burrows (ed.), Deciphering the Enterprise Culture, London: Routledge.

Granovetter, M. (1985) 'Economic Action, Social Structure and Embeddedness', American Journal of Sociology, 91, 4, 481-510.

Gratton, L., Hope Hailey, V., Stiles, P. and Truss, C. (1999) Strategic Human Resource Management, Oxford: Oxford University Press.

Hall, M., Lister, R. and Sisson, K. (1998) The New Law on Working Time. London: Eclipse/IRRU.

Hendrie, K. (1993) "'Invisible Threads": From Homeworkers to the High Street; Investigating the Links in the Sub-Contracting Chain', Uunpublished MA thesis: University of Warwick.

Hendry, C., Arthur, M. B, and Jones, A. M. (1995) Strategy Through People: Adaptation and Learning in the Small-Medium Enterprise, London: Routledge.

Herman, H. (1979) 'Dishwashers and Proprietors: Macedonians in Toronto's Restaurant Trade', in S. Wallman (ed.), Ethnicity at Work, London: Macmillan.

Hill, S. R. (1974) 'Norms, Groups and Power', British Journal of Industrial Relations, 12, 2, 213-35.

Hoel, B. (1982) 'Contemporary Clothing Sweatshops', in J. West (ed.), Work, Women and the Labour Market, London: Routledge and Kegan Paul. 
Holliday, R. (1995) Investigating Small Firms, London: Routledge.

Ingham, G. (1970) Size of Industrial Organization and Worker Behaviour, Cambridge: Cambridge University Press.

Kitching, J. W. (1997) 'Labour Regulation in the Small Service Sector Enterprise'. Unpublished PhD thesis: Kingston University.

Low Pay Commission (2000) The National Minimum Wage: The Story So Far. Cm 4571. London: Stationery Office.

Lucas, R. 1995. Managing Employee Relations in the Hotel and Catering Industry. London: Cassell.

Lucas, R. and Radiven, N. (1998) 'After Wages Councils: Minimum Pay and Practice', Human Resource Management Journal, 8, 4, 5-19.

McGovern, P., Hope Hailey, V. and Stiles, P. (1998) 'The Managerial Career After Downsizing', Work, Employment and Society, 12, 3, 547-77.

McNabb, R. and Whitfield, K. (2000) "'Worth So Appallingly Little": A Workplace-Level Analysis of Low Pay', British Journal of Industrial Relations, 38, 4, 585-610.

Mintzberg, H., Ahlstrand, B. and Lampel, J. (1998) Strategy Safari, London: Prentice Hall.

Mitter, S. (1986) 'Industrial Restructuring and Manufacturing Homework', Capital and Class, 27, $37-80$.

Moule, C. (1998) 'The Regulation of Work in Small Firms', Work, Employment and Society, 12, 4, $635-54$.

Phizacklea, A. (1990) Unpacking the Fashion Industry, London: Routledge and Kegan Paul.

Rainnie, A. (1989) Industrial Relations in Small Firms, London: Routledge.

Ram, M. (1994). Managing to Survive, Oxford: Blackwell.

Ram, M., Abbas, T., Sanghera, B., Barlow, G. and Jones, T. (forthcoming) “'Apprentice

Entrepreneurs”? Ethnic Minority Workers in the Independent Restaurant Sector', Work, Employment and Society.

Rowson, B. and Lucas, R. (1999) 'Employment Relations Issues in Small Firms'. Paper presented at the British Universities Industrial Relations Association, 15 December.

Rubery, J. (1997) 'Wages and the Labour Market', British Journal of Industrial Relations, 35, 2, 337-62.

Smith, C., Child, J. and Rowlinson, M. (1990) Reshaping Work, Cambridge: Cambridge University Press.

TCSG (Textile and Clothing Strategy Group) (2000) A National Strategy for the UK Textile and Clothing Industry, London: Department of Trade and Industry.

Totterdill, P. and Zeitlin, J. (1989) 'Markets, Technology and Local Intervention', in P. Hirst and J. Zeitlin (eds.), Reversing Industrial Decline, Oxford: Berg.

Werbner, P. (1990) 'Renewing an Industrial Past: British Pakistani Entrepreneurship in Manchester', Migration, 8, 7-41.

Wilkinson, A. (1999) 'Employment Relations in SMEs', Employee Relations, 21, 3, $206-17$.

Zhou, M (1992) Chinatown: The Socioeconomic Potential of an Urban Enclave, Philadelphia: Temple University Press.

Monder Ram

Faculty of Business and Law

Department of Corporate Strategy

De Montfort University

The Gateway

Leicester

LE1 9 BH

Accepted March 2001

email:mram@dmu.ac.uk 